Например, к началу ветвления высота растения в среднем не превышала 12,1 - 17,6 см.

Заметные различия высоты растений по вариантам опыта стали проявляться в фазу бутонизации. Высота растений в этой фазе развития нута изменялась в пределах 16,5 - 32,6 см, в зависимости от водообеспеченности.

$$
* * *
$$

1. Адиньяев Э.Д., Абаев А.А., Хугаева Л.М., Танделова Э.А., Тедеева В.В. Агротехнические особенности возделывания зернобобовых культур в лесостепной зоне РСО-Алания // Известия Горского государственного аграрного университета. 2013. Т.50 №4 С.29-35

2. Абаев А.А., Тедеева А.А., Мамиев Д.М., Тедеева В.В. Влияние сроков посева на продуктивность различных сортов сои // Научная жизнь. 2016. №5. С.33-42

3. Тедеева А.А. Биологические особенности районированных сортов гороха в период созревания и уборки в предгорных условиях РСО-Алания. Диссертация на соискание ученой степени кандидата биологических наук. Владикавказ. 2006. 169с.

4. Тедеева В.В., Абаев А.А., Тедеева А.А. Особенности минерального питания посевов нута // Научная жизнь. 2015. №2. С.38-45

5. Тедеева В.В., Абаев А.А., Хохоева Н.Т., Тедеева А.А., Казаченко И.Г. Улучшенная технология возделывания перспективных сортов нута в условиях предгорной зоны Центрального Кавказа // Владикавказ, 2014.

6. Тедеева А.А., Абаев А.А., Хохоева Н.Т. Продуктивность чины посевной в зависимости от сроков и норм высева в условиях предгорной зоны РСО-Алания // Вестник АПК Ставрополья. 2016. № 2 (22). C. 232-234.

\title{
Тедеева В.В.
}

\section{Эффективность применения баковых смесей гербицидов на посевах нута}

Северо-Кавказский научно-исследовательский институт горного и предгорного сельского хозяйства - филиал ФГБУН Федерального иентра « Владикавказский научный иентр РАН» (Россия, Михайловское)

doi: 10.18411/j-06-2020-09

idsp: ljournal-06-2020-09

\section{Аннотация}

В работе изучено влияние баковых смесей гербицидов на посевах нута. Приведены результаты применения гербицидов, нами доказано, что баковые смеси гербицидов Галакси топ с Набу-С наиболее полно подавляло все виды сорной растительности и позволило получить наибольшую прибавку урожая в сравнении с вариантами без обработки - 5,7-6,9 ц/га. Весьма эффективно было также сочетание Галакси топ 1,4 + Зеллек-супер 0,5 - урожай семян до 16,5 ц/га.

Ключевые слова: нут, гербициды, засоренность посевов, урожайность.

\section{Abstract}

In the work, the effect of tank mixtures of herbicides on chickpea crops was studied. The results of the use of herbicides are presented, we have proved that tank mixtures of Galaxy top herbicides with Nabu-S most completely suppressed all types of weed vegetation and allowed to obtain the highest yield increase in comparison with untreated options - 5.7$6.9 \mathrm{c} / \mathrm{ha}$. The combination of Galaxy top $1.4+$ Zelleck-super 0.5 was also very effective seed yield up to $16.5 \mathrm{c} / \mathrm{ha}$.

Key words: chickpeas, herbicides, weediness of crops, productivity.

Важное значение имеет нут в системе земледелия. Как зернобобовая культура, нут способствует сохранению плодородия почв, экономит материальные средства за счет снижения количества вносимых азотных удобрений. После уборки нута остается 
большое количество богатых азотом корневых и пожнивных остатков, которые разлагаясь, стимулируют активность микрофлоры почв $[1,3]$.

Расширение районов возделывания этой культуры не возможно без применения химических средств защиты, в т.ч. гербицидов. На 1 га посевов этой культуры необходимо вносить около 2 кг гербицидов, и доля затрат на применение этих препаратов постоянно растет. На 30 \% площадей гербициды под нут вносят до посева, примерно на $14 \%$ - при севе (иногда сочетая это с внесением бактериальных удобрений), на $12 \%$ - до всходов, на $20 \%$ - комбинируя эти способы. Все большее внимание уделяют применению послевсходовых селективных гербицидов, так как они действуют на вегетирующую сорную растительность и могут применяться при любых способах обработки почвы $[5,6]$.

Поэтому усовершенствование химических мер борьбы с засоренностью на посевах нута в условиях лесостепной зоны РСО-Алания является актуальной задачей современного земледелия.

Цель исследований заключалась в изучении действия различных гербицидов и их сочетаний на показатели продуктивности перспективных сортов нута.

Методика проведения исследований. Опыты закладывали на экспериментальном поле СКНИИГПСХ ВНЦ РАН в 2016-2018 гг. Повторность опытов четырехкратная. Общая площадь делянки - 17-25 м². Расположение делянок рендомизированное. Посев проводили с междурядьями 45 см и нормой - 400 тыс. семян/га.

Результаты исследования. Для расширения спектра действия на сорную растительность нами было изучено действие гербицидов при последовательном их применении. Основные препараты вносилось перед посевом, при появлении всходов культуры применялись дополнительные препараты. Харнес, Дуал голд, Гезагард, Фронтьер в дозах соответственно: 3,$0 ; 1,5 ; 2,5 ; 1,5$ кг/га д.в. применялись в качестве основных препаратов, Пивот - 0,7 кг/га д.в. - в качестве дополнительного.

Наиболее эффективным было применение смеси Харнес 3,0; Пивот 0,7, которое лучше остальных подавляло сорную растительность. При данной комбинации засоренность посевов в 2013 году снизилась на 94,3\%, на 97,5\% уменьшилась биомасса сорняков. Несколько ниже была эффективность варианта с Дуал голд 1,5; Пивот 0,7. Количество сорняков уменьшилось на 75,7\%, на 78,4\% - снизилась биомасса. Общее количество сорняков на контроле было равно 90,2 шт./м². Сухая биомасса их

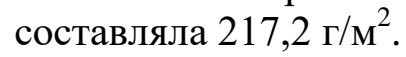

Эффективность гербицидов, как было установлено, зависела во многом от биологического состава сорной растительности, а также устойчивости их к используемым препаратам, распределения и выпадения осадков после обработки, доз и сроков применения средств. При повышении показателей температуры почвенного покрова и воздуха чувствительность сорняков к применяемым препаратам значительно возрастала, так как с повышением температуры скорость обмена веществ в растительных организмах также возрастает и токсичность используемых сочетаний в итоге повышается. Осадки, особенно ливневые, выпавшие непосредственно после обработки, как показали исследования, эффективность препаратов значительно снижали вследствие смыва последних [7,8].

Посевы нута после внесения основных гербицидов были относительно чистыми в течение 2-3 недель, после чего количество сорняков увеличивалось. Поэтому применялся страховой препарат Пивот, который вызывал некоторую задержку в развитии растений нута. Наблюдалась деформация листовых пластинок, желтели верхние листочки. Определенное влияние не только на сорняки, но и на нут с момента его прорастания (густота всходов несколько уменьшалась, проростки культуры угнетались) оказывал также гербицид Фронтьер. 
Практически на 100 \% Харнес подавлял следующие виды сорняков: осот желтый, гречишка вьюнковая, ярутка полевая, пастушья сумка, подмаренник цепкий. Примерно аналогичная тенденция проявлялась во все годы исследований.

Как известно, разложение любых химических веществ в организме происходит за счет ферментов. При использовании смеси из нескольких гербицидов, на их разложение и детоксикацию растительных организмов необходимо большее количество различных ферментов $[2,5]$.

В такой ситуации провести детоксикацию действующих гербицидов без затрат и быстро растение, в большинстве случаев, не в состоянии, поэтому процессы обмена веществ в нем протекают со значительными нарушениями, что приводит к сильному угнетению или гибели. У растений, которые выработали некоторую устойчивость к тем или иным гербицидам, данное явление протекает наоборот, то есть при одновременном внесении гербицидов ферментативный аппарат устойчивых растений действующие вещества гербицидов разлагает без особых затрат энергии и времени [4].

В наших опытах изучали сочетания в баковых смесях гербицидов Галакси топ, Набу-С и Зеллек супер. Установлено, что сочетание Галакси топа с противозлаковым гербицидом Набу-С способствовало более полному подавлению всех видов сорной растительности. Вариант Галакси топ $1,4+$ Зеллек-супер 0,5 был также очень эффективным - обеспечил получение 16,5 ц/га семян нута (табл. 1).

Таблийа 1

Эффективность применения препарата Галакси топ в сочетании с противозлаковыми гербицидами на посевах нута

\begin{tabular}{|c|c|c|c|c|c|c|}
\hline \multirow[b]{3}{*}{ Вариант } & \multicolumn{4}{|c|}{ Масса сорняков, \% к контролю } & \multirow[b]{3}{*}{$\begin{array}{c}\text { Снижение } \\
\text { засоренности, } \\
\%\end{array}$} & \multirow[b]{3}{*}{$\begin{array}{c}\text { Урожай } \\
\text { семян, ц/га }\end{array}$} \\
\hline & \multirow[b]{2}{*}{ вcex } & \multicolumn{3}{|c|}{ в том числе } & & \\
\hline & & 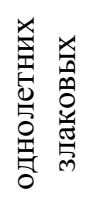 & 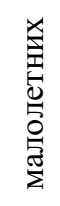 & 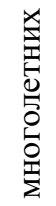 & & \\
\hline $\begin{array}{c}\text { Контроль } \\
\text { (без гербицидов) }\end{array}$ & - & - & - & - & - & 9,9 \\
\hline $\begin{array}{c}\text { Галакси топ, 1,2 л/га + } \\
\text { Набу-С, 1,5 л/га }\end{array}$ & 90 & 94 & 89 & 87 & 87 & 15,6 \\
\hline $\begin{array}{c}\text { Галакси топ, 1,4 л/га + } \\
\text { Набу-С, 1,5 л/га }\end{array}$ & 93 & 96 & 92 & 90 & 90 & 16,8 \\
\hline $\begin{array}{c}\text { Галакси топ, 1,6 л/га + } \\
\text { Набу-С, 1,5 л/га }\end{array}$ & 91 & 94 & 88 & 90 & 91 & 15,9 \\
\hline $\begin{array}{c}\text { Галакси топ, 1,4 л/га + } \\
\text { Зеллек-супер, 0,5 л/га }\end{array}$ & 93 & 96 & 91 & 90 & 94 & 16,5 \\
\hline $\mathrm{HCP}_{05}, ц / г \mathrm{a}$ & & & & & & 0,74 \\
\hline
\end{tabular}

Гербициды не оказывали отрицательного влияния на процессы вегетативного роста и развития посевов нута. В 2016 году, правда, во время опрыскивания по данным визуальных наблюдений отмечались ожоги листьев, однако на дальнейшем развитии культуры это не отразилось.

Как выявлено исследованиями, наиболее опасным критическим периодом для нута являются 15-30 суток после появления всходов. Поэтому необходимо 
поддержание посевов нута в чистом виде - основная послепосевная задача. Удаление сорняков в более поздние сроки уже не компенсирует потерь, нанесенных формированию урожая.

Высокий урожай семян любой сельскохозяйственной культуры может быть получен может быть получен только при обеспечении всеми необходимыми условиями для формирования площади ассимиляционной поверхности (световой, тепловой, водный, воздушный, пищевой режимы). Интенсивное нарастание массы листьев в начальные периоды вегетации приводит к затенению посевов, что отрицательно сказывается на качестве формирующихся бобов и, следовательно, на количестве собранного урожая. Применение гербицидов в посевах нута способствовало стимулированию активности фотосинтетического аппарата. Площадь листовой поверхности изучаемых вариантов превышала контрольные на 2,5-8,3 тыс. м²/га.

Как показывает анализ структуры урожая, повышение урожайности происходило за счет увеличения количества бобов и зерен на одном растении на 42 $54 \%$. Кроме того, на вариантах с применением гербицидов растения нута превосходили контрольные по высоте и массе. Сочетание Галакси топа с Набу-С повышало массу 1000 зерен на 9-15 г в сравнении с контролем и не оказывало влияния на энергию прорастания и всхожесть семян. Определение остаточных количеств гербицидов показало, что ко времени уборки урожая они полностью инактивировались как в зерновой массе, так и в почве.

Таким образом, наиболее эффективной защитой от подавления сорной растительностью растений нута является сочетание препаратов: Харнес 3,0; Пивот 0,7 и Дуал голд 1,5; Пивот 0,7 и баковая смесь топ + Набу-С + Зеллек супер. Сочетание препаратов Галакси топа и Набу-С способствует более полному подавлению всех видов сорняков и получению значительной прибавки к урожаю относительно контрольных вариантов (прибавка 5,7-6,9 ц/га). Сочетание Галакси топ 1,4 + Зеллек супер 0,5 было также весьма эффективно (урожайность - 16,5 ц/га семян). Применяемые гербициды не оказывали угнетающего действия на последующие культуры в севообороте, не накапливались в зерновой массе и почве.

$$
* * *
$$

1. Нецветаев В.П., Тютюнов С.И., Правдин И.В., Петренко А.В. Нут - перспективная бобовая культура в условиях изменения климата юго-запада ЦЧР РФ // Зернобобовые и крупяные культуры. 2016. № 2 (18). С. 137-143.

2. Тедеева В.В., Абаев А.А., Тедеева А.А., Хохоева Н.Т. Показатели фотосинтетической деятельности нута в зависимости от способа посева, нормы высева и гербицида // Современные проблемы науки и образования. 2015. № 1-1. С. 1696.

3. Тедеева В.В., Абаев А.А., Хохоева Н.Т., Тедеева А.А., Казаченко И.Г. Улучшенная технология возделывания перспективных сортов нута в условиях предгорной зоны Центрального Кавказа. Владикавказ, 2014. - 48 с.

4. Тедеева А.А., Абаев А.А., Хохоева Н.Т. Продуктивность чины посевной в зависимости от сроков и норм высева в условиях предгорной зоны РСО-Алания // Вестник АПК Ставрополья. 2016. № 2 (22). C. 232-234.

5. Тедеева В.В., Хохоева Н.Т., Тедеева А.А. Влияние гербицидов на засоренность нута // Известия Горского государственного аграрного университета. 2014. Т. 51. № 4. С. 34-38.

6. Черкашин В.Н., Черкашин Г.В., Коломыцева В.А. Поиск препаратов для защиты посевов сои и нута // Защита и карантин растений. 2017. № 8. С. 24-25.

7. Алехин В.Т. Пути оптимизации защиты зерновых культур // Защита и карантин растений. 2014. № 8. C. 3-8.

8. Карпухин М.Ю., Гринец Л.В. Влияние минеральных удобрений на урожайность культур в зависимости от технологии возделывания // Аграрный вестник Урала. 2016. № 5. С. 6-10. 